\title{
NEOPAGANISM AND NEW AGE IN RUSSIA
}

\section{Anne Ferlat}

Since the 1990s various new pagan organisations have emerged in Russia. Religious phenomena known in Western Europe, such as the emergence of new religious movements, including the New Age, are also taking place in Russia. The article aims to find out whether the pagan movements in today's Russia are related and if so, how they are related according to the comparative perspective explicated by Michael York, Paul Heelas and Wouter Hanegraaff.

In The Emerging Network, Michael York (1995) affirms that the main three characteristics of Neopaganism and New Age are the stewardship of the Earth, personal growth, and religious consumerism. I will observe whether these characteristics apply to Neopaganism and New Age in Russia.

We will focus on self development, which is one of the key notions in New Age, in order to observe how this notion is presently understood in the specific context of post-communist Russia, as well as the relationship with nature, "strongest overlap between Neopaganism and New Age. Both of these concepts are important in regard to the form that contemporary pagan organisations have assumed: some emphasise nationhood and people, though its members may make references to the western New Age literature, while others try to revive the past and the link with the Earth, which still existed in early 20 th century rural communities owing to the "double faith".

It appears that the New Age and Neopaganism share the same goals: namely, letting the integral voice of each individual express itself after freeing the self from one's conditioning. In the New Age framework this means to independent thinking, living according to one's own values and personality and not according to what society, culture, parents have imposed on you. It means also discovering one's own creativity. In The Emerging Network, Michael York affirms that the unity of New Agers, despite their contradictory opinions and beliefs, finds itself in the "vision of radical mystical transformation 
on both personal and collective levels." He also introduces the concept of immanence, the concept of a God and Goddess which is to be found everywhere in nature and within each individual. He analyses Neopaganism as personal development and responsibility; the New Age and Neopaganism both share the belief in the intrinsic divinity of the individual. Therapy and healing constitute an important part of the New Age and Neopagan practices. Wouter Hanegraaff has pointed out the influence of Jung on the Neopagan movement, speaking of the psychologisation of esotericism and of the sacralisation of the psyche (Hanegraaff 1996). Psychologisation stands for the means to cure the soul and the mind in the different traditions. If we refer to Jung himself, his descriptions of the cure are along the same lines with immanence, letting the mystery of life operate after the individuation process. To complete this process it is necessary to suffer; and, to be more precise, the therapies or seminaries proposed by the New Age aim to solve the problems that one have encountered in infancy and heal the wounds of childhood. Jung refers to this individuation process and draws comparisons between some of the methods which lead to it: therapy, Zen, alchemy. This occurs when the individual has integrated his shadow. The individual ceases to react, to be acted upon, but acts on his own. And once this has happened, he can enter into a creative process, he is able to express himself, he will be able to discover his creative part, his true identity. The identity is the central theme of both the New Age and Neopaganism. It is a matter of an individual but also of culture. "Unlike Purists," Paul Heelas writes, "counterculturalists are intent on developing all that is authentic, expressive person." (Heelas 1996: 31). He argues that "various uncertainties of modernity generate identity problems which propel people to do something about their situation; various certainties of modernity direct such people to seek solutions by way of New Age provisions." (Heelas 1996: 137). Detraditionalization means that a person frees himself/ herself from conditionings and becomes valued for self and not according to the social or educational criteria. One is no more an object but becomes a full-fledged individual, losing one's utilitarian function.

Criticism addressed to the New Age and Neopaganism concerns the possible individualism which arises from such concepts. But if we adopt the perspective of the true Self and overcome the ego as 
part of the individuation process, the criticism is no longer possible. The individuation process opposes individualism. The individual is no more dependent on external conditions but fully participates in existence. He can create as well as serve humanitarian aims. This is also a unification process of personality in which one's potential is optimised as one solves his contradictions and balances the functions which constitute a personality. This notion is described in Dreaming the Dark, Magic, Sex and Politics by Starhawk (1983). She opposes "power on" and "power from within," which fits this notion of overcoming the ego to reach the Self.

Another point concerning power and the expression of the Self is the literature on victims and the phenomena of victimisation which emerged some years ago first in the United States, then in Europe. In Magical Religion and Modern Witchcraft edited by James Lewis, Sian Reid emphasizes this aspect of powering referring to "an aspect of subjective experience common to many witches and this was noted by Shelley Rabinovitch M.A. on Neopagan witchcraft in Canada; the experience of an abusive or severely dysfunctional background"(Reid 1996: 141). Reid's development concerns the effects of magic and he compares the boundaries that magic allows and the training necessary to practice magic within the boundaries that therapy brings to the victims of abuse. Magic, like therapy, allows the individual to reinforce himself/herself. Reid argues that "the self-discovery process is the same one advocated in the self help literature directed at abuse victims." (Reid 1996: 151). She also compares the techniques proposed to victims with magical trainings. Both aim to heal the individual. Remedial spells are directed at the unconscious in order to communicate with the younger self, the core of personality, the seat of emotions which is hidden by the intellect and the talking self. In case of abuse, the younger self is unable to express itself. The individual is cut off from his/her emotions and often from reality itself. If one does not learn to say no, there is no boundary between him and the external world. He cannot set limits and find his own personality, which means that he is not an individuated person. He is not free but an eternally submissive child. In French literature on the topic, psychiatrist MarieFrance Hirigoyen has enjoyed great success with her book Stalking the Soul, Emotional Abuse (2000). She describes the process of emotional abuse which leaves people in a state of depression and guilt, 
leading to a total erosion of identity. There are now plenty of such studies on this notion of power and emotional abuse and the notion of tyranny. Very often, the aggressor himself or herself is a victim and repeats the pattern. This is what she calls the perversion of narcissism. If we consider the two millennia of the Christianity which has established that an individual is sinful by birth, ideologies such as capitalism and Marxism, which propagated a utilitarian perception of a human being and imposed their power on an individual while promoting the collective, each in its own way, could we not say that the whole society is somewhere the victim of power abuse? So Neopaganism and the New Age might wish to escape this victimised state. Self development and sacralisation of the Self appear as the will to develop the inner strength to choose one's course of life. Traumas and power abuse kill something in the person and block vital energy. In celebrating life in all its forms and aspects, Neopaganism affirms the sacred against the forms of power which prevent taking full advantage of life. It refutes all kinds of dogmas to let life affirm its own right. It is not a narcissistic view of the world and the promotion of ego, but the affirmation to live in conformity with one's true self. The revival of paganism in Western countries today would be the unconscious research to ward the triumph of life, free the blocks which prevent vital energy to fully express it. Perhaps, this is also one of the meanings of immanence present in literature on Neopaganism. Apart from this triumph of life, the notion of self-responsibility refers to Jung's psychology. The aim here is to become an adult in the strict sense of the word. It is the dream of an adult humanity free of its bad tendencies: hate, revenge and all infantile feelings and acts.

Now we are going to see whether these notions make sense in the Russian Neopagan movements. In order to contextualise the situation, it is necessary to say a few words on the New Age in Russia. The New Age movement in Russia has adopted several forms similar to the Western one. Different websites attest to the emergence of several New Age groups in Russia. Thus we find groups such as "Worlds of Consciousness" which offers conferences on "Choosing your future", and trainings to expand consciousness. There is a newsletter "Messenger of Transmutation", which aims to facilitate the understanding of the world formation process, laws governing life and karma, and the ability to choose the way of one's improve- 
ment. On its site Shamballah, the Russian esoteric centre describes its provisions as a mix of traditions referring to "the mysterious studies of the people of Siberia, the Altai and Central Asia, the hidden esoteric side of the Russian pre-Christian belief and Shamanism. It teaches ancient magic, the art of healing and the understanding of trees, animals and Shamanism. It affirms that "only everybody's wealth and happiness can contribute to a sound society" and also that the "magic of beauty helps us to feel brighter and feel full of joy, and to change the attitude toward ourselves." Some other organisations refer to the pagan gods, reincarnation and meditation. They teach magic, "grey magic", for example, which means "all types of magic without any exclusion but without harming anyone." The New Age is also present in Neoshamanism which began in Russia with the publication of the books by Carlos Castaneda in the 1980s, causing much trouble for people who became adepts and practised Shamanism by consuming mushrooms without proper awareness. Today Castaneda is popular in Russia but the internet sites referring to his work warn about the possible dangers of the proposed practices. In the 1990s the Transpersonal Institute in Moscow published The Way of the Shaman by Michael Harner. The institute organises sessions of holotropic breathwork according to the Stanislavs Grof's method. Nevertheless it is necessary to note that Michael Harner represented the starting point for a form of Neo-shamanism in many other countries as well. Michael Harner and his Shamanic trainings remain a source of reference for many people on different paths interested in Shamanistic practices. They cover the same notions as in the Western countries, perceiving Shamanic cosmos as the strata of the human psyche (Ferlat d'Apremont).

Literature on the New Age is distributed under the name of Neopaganism even though there are not many mind, body and spirit bookshops. The situation of the new religious movements troubles the Church as well as the government. During a conference held in Moscow in January 2002, Vladimir Zorkaltsev, the president of the Committee on religious and public organisations at the Duma, argued that "freedom recovered by the Church and other traditions has not made anything easier. Our country is now submerged by all kinds of pseudo-religious organisations, of mystical and occult groups, and of cheap literature which is spread without any control. Society 
is exposed and traditional confessions are paralysed by this menace." (www.religioscope.com) This alarming analysis might lead to more restrictions than those imposed by the 1997 Law of Freedom of Religions.

Of all the Neopagan movements, 41 are officially registered by the Ministry of Justice. This number does not cover all organisations as some of them are very small and not registered.

Since the article is based on work still in progress, it is too early to establish a typology of Russian pagan movements but a primary typology could be a negative / positive view of life in the light of the development of pagan movements: by reaction against something, particularly Christianity with an anti-Christian discourse, or in a positive way, i.e. to promote old traditions and to develop another way of perceiving the world and the living.

Today, especially in Russia, the number of Slavic pagan groups is growing parallelly to the rest of Europe and North America.

The first groups developed out of the Russian folklore research of the 1970 s and the 1980 s. The second significant wave occurred in the 1990s with Perestroika allowing more self-expression. At this point, some pagan groups have come to emphasize the relationship between the Slavic traditions and Hinduism or between the Slavic traditions and Indo-European roots. Another emerging characteristic is the nationalistic, even a national socialist orientation of some groups. This also includes an emphasis on the worship of the god Perun, god of thunder and lightning, incarnation of the warrior, who had originally become the dominant Slavic deity just before Christianisation. Another, more mystical tendency concerns the cult of the god Veles, who was traditionally associated with nature and cattle. But an essential feature of Russian Neopaganism is its focus on the Slavic martial arts - an aggressive aspect that attracts many people. Another reason for the present interest in pre-Christian times is the emergence of fantasy literature concerning the adventures of pagan heroes and describing the early pre-Christian period as Russia's Golden Age. The present tendency among the Slavic Neopagan groups is to construct a coherent movement with established worship and rituals. However, this development is eclectic and not purely Slavic - being constructed from the Celtic, 
Scandinavian and Hindu components in addition to any Slavic recoveries. This search for unity is often based on The Book of Vles, a series of inscriptions on small boards discovered by a soldier in 1919 . The authenticity of this work, however, is highly contested by scholars. Nevertheless, in these developments we witness that Slavic Paganism today is sometimes more of an intellectual construction based on a search for identity than a feeling of unity with the universe and nature.

Answers to the questionnaires sent to these groups reveal that goddesses are less represented while they are present in the literature of those groups that revere the earth and nature according to the traditions which continued until the early 20th century, under the concept of double faith which associated Pagan and Christian practices, particularly in rural regions. But it has also been observed that if Neopaganism attaches importance to nature, the behaviour does not always correspond to their conception. Again, it is too early to conclude but it seems that the more nationalistic trends these groups develop, the less ecologically-minded they are. Other groups belonging to non-nationalistic movements are definitely concerned with individual ecological actions such as cleaning up the forests. Russia lacks serious ecological culture in the way people behave towards nature. The key notions of Neopaganism in today's Russia are vera, meaning 'faith' and 'confidence' and the worship of ancestors. Most Neopagans consider Paganism as a way of seeing the world and aim to develop themselves. Nationalistic groups are more concerned with the idea of people and a form of proselytism, while non-nationalistic are more centred at the restoration of one's own skills and self-improvement. Some assert that they, like their ancestors, practice techniques embedded in the Slavic tradition, such as the use of herbs and materials.

In the concept of reincarnation, which is a common notion to both New Age and Neopaganism, we can distinguish between three points of view: reincarnation as it is presented in the New Age, the passage of a soul in a realm called Nav, which represents the immaterial world. Sometimes the soul reaches Prav, the world of the god Svarog, or comes back in the material world called Jav.

Neopaganism in Russia shares a holistic view of the world with Western Neopagan movements, and both ethnic and non-ethnic 
movements adhere to this view. For example, some followers of the Northern traditions in Western countries have adopted the concept of Wyrd, as Brian Bates has described in his work. In Russia, New Age groups use pagan concepts and references while some Neopagans use New Age concepts or have New Age practices as it was seen during the gathering in Kaluga in July 2001, reflecting a mix of traditions. It also appeared that some members of these groups follow Buddhist teachings. This applies to members of the group Soltnsevorot, meaning "solstice".

The self in this context might refer to the return of the person and the individual after collectivism and forced atheism. Nevertheless, despite the official ideology one must not forget that the Church continued to exist in the catacombs. Babas, the grandmothers, continued to narrate tales and this also kept the memory alive. Folklore continued to exist in some parts of Russia and Communism also used it in attacking Orthodoxy. As we have seen, the self is very often a matter of ethnic identity. The affirmation of life is at the centre of the conscious concerns of these groups. This is also evident in the numerous celebrations held throughout the year.

In conclusion, it is difficult to predict how these movements will evolve in Russia and how the New Age will have an impact on both society and individuals. The overall situation both in the Western countries and Russia raises more questions than can be answered: the question is, whether the concept of movements clashes with the internal freedom of individuals and how to prevent some individuals from dominating the collective? Is not the common basis that those groups develop just another form of conditioning? Are these groups simply another form of mass culture? Do the groups pose a risk on individuals?

It seems we are more and more conscious of this notion of power in the Western countries but will Russia follow the same way? And while freedom of religion is not completely asserted, how will people be able to express themselves?

To what degree is the time we live in changing? How permanent are these changes? And, finally, who are the people involved? 
Paul Heelas points to detraditonalization and maybe it is possible to say that we are witnessing a re-traditionalisation in the sense of a rediscovery of the divine nucleus within a man.

\section{References}

Ferlat, Anne. Shamanism today in Russia. Encyclopedia of Shamanism. Santa Barbara: ABC Clio. In press.

Hanegraaff, Wouter J. 1996. New Age Religion and Western Culture: Esotericism in the Mirror of Secular Thought. Studies in the history of religions 72. Leiden \& New York: E. J. Brill.

Heelas, Paul 1996. The New Age movement: The celebration of the self and the sacralization of modernity. Oxford \& Cambridge: Blackwell.

Hirigoyen, Marie-France 2000. Stalking the Soul: Emotional abuse and the Erosion of Identity. New York: Helen Marx Books.

Jung, Carl Gustav 1991. The Development of Personality. London: Routledge.

Reid, Sian 1996. "As I do Will, So Mote it Be": Magic as Metaphor in Neopagan Witchcraft. James Lewis (ed.). Magical Religion and Modern Witchcraft. Albany: State University of New York Press, pp. 141-167.

Starhawk 1983. Dreaming the Dark, Magic, Sex and Politics. Boston: Beacon Press.

York, Michael 1995. The Emerging Network:A sociology of New Age and Neo-Pagan Movements. Lanham: Rowman \& Littlefield Publishers. 